\title{
Small mammal fauna of Early Pleistocene age from the Xiaochangliang site in the Nihewan Basin, Hebei, northern China
}

\author{
Yingqi Zhang*1, Yoshinari Kawamura*2, a and Baoquan Cai*3
}

\begin{abstract}
A large amount of sediments was taken from the horizon stratigraphically equivalent to the artifact layer in the Xiaochangliang site, an important archaeological site of Early Pleistocene age. The sediments were washed with fine-mesh screens to collect small mammal remains. The layer is dated as $1.36 \mathrm{Ma}$ by paleomagnetic measurements. Small mammal remains are important for biostratigraphic and paleoenvironmental studies, but they have been hardly collected from the site before the present study. A large number of the remains collected by the screen-washing have revealed the characteristics of the small mammal fauna of the site. The fauna is compared with those of the four well-dated localities in the adjacent area. On the basis of the faunal characteristics and comparisons, we discuss the biostratigraphy and faunal turnover in the Late Pliocene and Pleistocene. Furthermore, we reconstruct the paleoenvironment around the site in the Early Pleistocene.
\end{abstract}

Keywords : small mammal fauna, biostratigraphy, Early Pleistocene, Xiaochangliang site, Nihewan Basin, China

\section{Introduction}

The Nihewan Basin situated about $150 \mathrm{~km}$ west-north-west of Beijing (Fig. 1) has been well known for geologists and paleontologists since the discovery of abundant mammalian remains of Early Pleistocene age in the later 1920's. The remains have occurred from fluviolacustrine sediments called the Nihewan Formation. In spite of a piece of information on the occurrence of a "stone artifact" from the basin (Breuil, 1935), archaeologists had paid little attention to the sediments of the basin, until paleolithic artifacts were discovered at the Xiaochangliang site in 1978 (You et al., 1980).
Since then, thousands of artifacts and more than 10 forms of mammals have been excavated from the site (Tang et al., 1995 ; Chen et al., 1999), but the knowledge on small mammals has been quite limited in previous works.

Because the site is important for considering human immigration into East Asia during the Early Pleisotcene, Zhu et al. (2001) tried to determine the detailed numerical age of the artifact layer of the site by paleomagnetic measurements. They concluded that the layer was dated as $1.36 \mathrm{Ma}$. Their conclusion is more detailed and more reliable than the results of faunal dating by previous authors.

In order to obtain sufficient knowledge on

Received July 12, 2007. Accepted November 17, 2007.

*1 Institute of Vertebrate Paleontology and Paleoanthropology, Chinese Academy of Sciences. P.O. Box 643, Beijing, 100044, China (Present address : Graduate School of Science, Osaka City University. 3-3-138 Sugimoto, Sumiyoshi-ku, Osaka, 558-8585, Japan).

*2 Department of Earth Sciences, Aichi University of Education. 1 Hirosawa, Igaya-cho, Kariya, Aichi Prefecture, 448-8542, Japan.

*3 Department of History, Xiamen University. Xiamen, Fujian, 361005, China.

*a Corresponding author : yskawamr@auecc.aichi-edu.ac.jp 


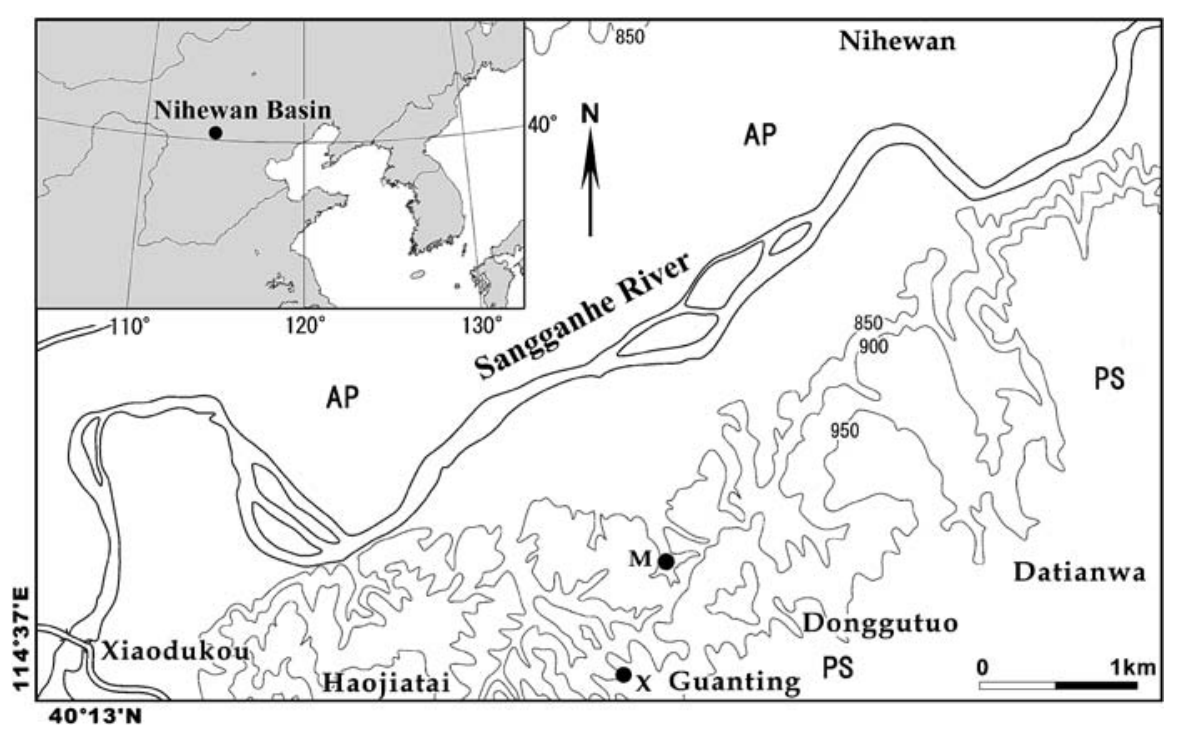

Fig. 1 Map showing the topography near the east-north-eastern end of the Nihewan Basin, where the Xiaochangliang site $(\mathrm{X})$ is situated

AP : alluvial plain of the Sangganhe River, PS : plateau surface, M : another archaeological site at Majuangou (“new cultural layer” of Cai and Li, 2003).

small mammals of the paleomagnetically welldated layer, a large amount of sediments was sampled from the layer, and was washed with fine-mesh screens. The screen-washing resulted in obtaining more than 200 remains of small mammals assignable to 10 forms, most of which were new to the mammalian fauna of this site. Small mammals are generally more important for biostratigraphy and paleoenvironmental reconstruction than large mammals. Thus in this paper, we describe the small mammal fauna of the site, compare it with other faunas, and discuss small mammal biostratigraphy, faunal turnover and paleoenvironment. The systematic descriptions for each form of small mammals will be given in subsequent papers.

\section{Geological setting}

The Xiaochangliang site is situated near the east-north-eastern end of the Nihewan Basin which shows a slender shape extending from this end toward west-south-west along the Sangganhe River into Shanxi Province. Around the site, Pliocene and Pleistocene sediments are well exposed in a hilly area between the alluvial plain of the Sangganhe River and a flat plateau surface about $150 \mathrm{~m}$ higher than the plain (Fig. 1). Several paleolithic archaeological sites found after the Xiaochangliang site are also distributed in the hilly area (for example, the Donggutuo and Majuangou sites). Cai et al. (2004) divided the sediments in the area and in the neibourhood with the same topography into such four units as 1) "Hipparion red clay" of early Pliocene age, 2) red, gray and grayish black fluvio-lacustrine silty clay of late Pliocene age, 3) brownish yellow to grayish yellow fluvio-lacustrine clay and gravel of Pleistocene age, and 4) overlying loess forming the plateau surface, in ascending order. The unit 3 is sometimes subdivided into the Nihewan Formation of Early Pleistocene age and the Xiaodukou Formation of Middle Pleistocene age (Yang et al., 1996 ; Wei, 1997, etc.).

The Xiaochangliang site was found on a small ridge called Xiaochangliang which means a small but long hill ridge in Chinese (Fig. 2-A). The ridge extends north-westward from the plateau edge near Guanting (Fig. 1). The section of the sediments are observable along the ridge. In the section, the units 1 and 2 of Cai et al. (2004) are lacking, while the units 3 and 4 are 


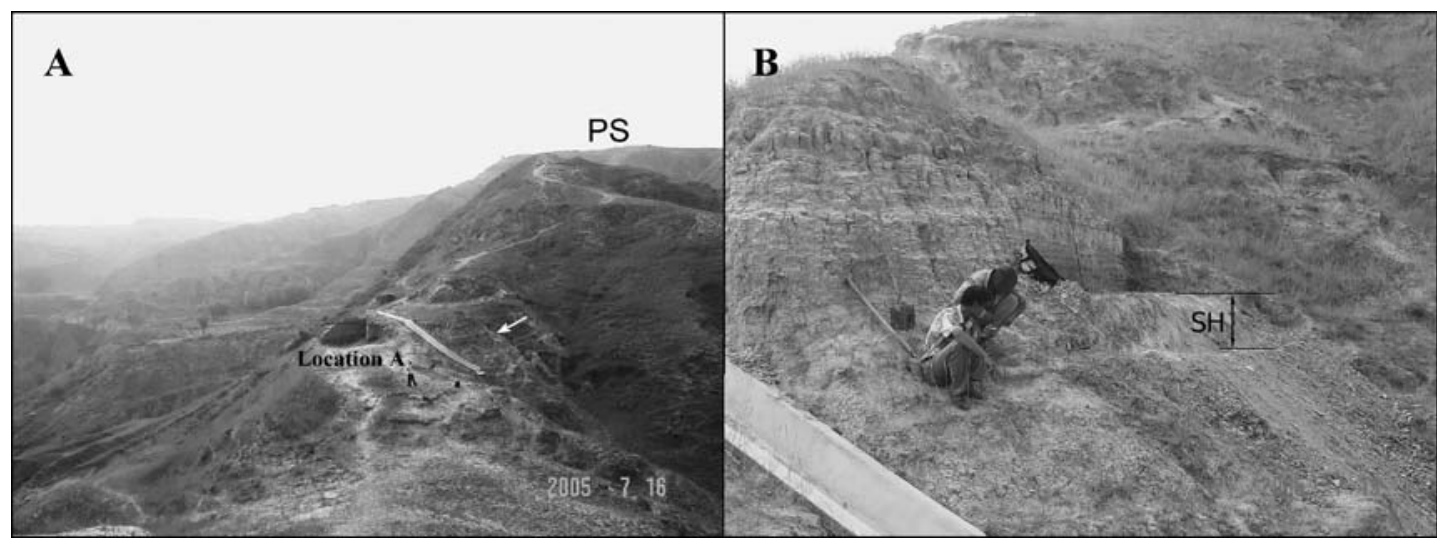

Fig. 2 Sampling site in "Location A" of the Xiaochangliang site

A : overall view from "Location B" showing the sampling site (arrow) on the western slope of the ridge extending from the plateau surface (PS), B : close-up photo of the sampling site showing the sampling horizon (SH).

present. The unit 3 overlies directly the Jurassic basement rocks with an unconformity and is covered by the unit 4. Zhu et al. (2001) showed a detailed stratigraphic sequence of the section with a thickness of $73 \mathrm{~m}$, which was composed mainly of silt and/or clay (Fig. 3). They also described a thicker sequence of the "Donggou" section $1 \mathrm{~km}$ west-south-west of the Xiaochangliang site (outside the map of Fig. 1). Unfortunately, they did not show the exact position of this section, and "Donggou" by them is different in position from the same place-name used by other authors, as discussed in the subsequent chapter. The "Donggou" section is correlative with the Xiaochangliang section, because the sequences of the two sections are almost identical, and contain sedimentological marker layers. Zhu et al. (2001) carried out detailed paleomagnetic measurements, and determined two normal and two reversed magnetozones in the Xiaochangliang section (N1, N2 and R1, R2), and three normal and two reversed magnetozones in the "Donggou" section (N1, N2, N3 and R1, R2). They correlated the magnetozones with the standard geomagnetic timescale, as shown in Figure 3. N3 correlative with the Olduvai Subchron is recognized only in the "Donggou" section, while N2 correlative with the Jaramillo Subchron is found in both of the sections. The sampling horizon of the present study ( $\mathrm{SH}$ in Fig. 3) is identical with the artifact layer of the site as stated in the next chapter. Zhu et al. (2001) estimated the age of the layer to be $1.36 \mathrm{Ma}$, because the average accumulation rate between the Jaramillo and Olduvai Subchrons was calculated at about 4.6 $\mathrm{cm} / \mathrm{ka}$ in the "Donggou" section which intercalated a thin marker layer of black silty clay $13.4 \mathrm{~m}$ below the Jaramillo onset ( $1.07 \mathrm{Ma}$ ), and because the same layer was also found at the top of the artifact layer of the Xiaochangliang site.

In the present paper, we adopt $2.6 \mathrm{Ma}$ as the boundary age of the Pliocene and Pleistocene instead of $c a .1 .8 \mathrm{Ma}$, the end of the Olduvai Subchron, as generally done among Chinese scientists.

\section{Sampling site and horizon}

Since the first excavation, the Xiaochangliang site has been divided into Locations $\mathrm{A}$ and $\mathrm{B}$ (Fig. 4). The geographic coordinates are $114^{\circ} 39.752^{\prime} \mathrm{E}$ and $40^{\circ} 13.181^{\prime} \mathrm{N}$ for $\mathrm{A}$, and $114^{\circ}$ $39.692^{\prime} \mathrm{E}$ and $40^{\circ} 13.188^{\prime} \mathrm{N}$ for B (Chen et al., 1999). The excavations of the site have been conducted in many grids as shown in Figure 4. We decided the sampling site on the western slope near the most south-western grid of Location A (Figs. 2-A and 4), because each layer of the sediments are horizontal and the artifact layer is expected to expose in the sampling site. As a result of our excavation, the marker layer of black silty clay with a thickness of $2 \mathrm{~cm}$ was found in the lower part of the section of the sampling site. 
Zhu et al. (2001) already described the marker layer lying just above the artifact layer of the Xiaochangliang site. Thus the sediments just below the marker layer in our section is stratigraphically equivalent to those of the artifact layer (SH in Fig. 2-B). They were sampled for

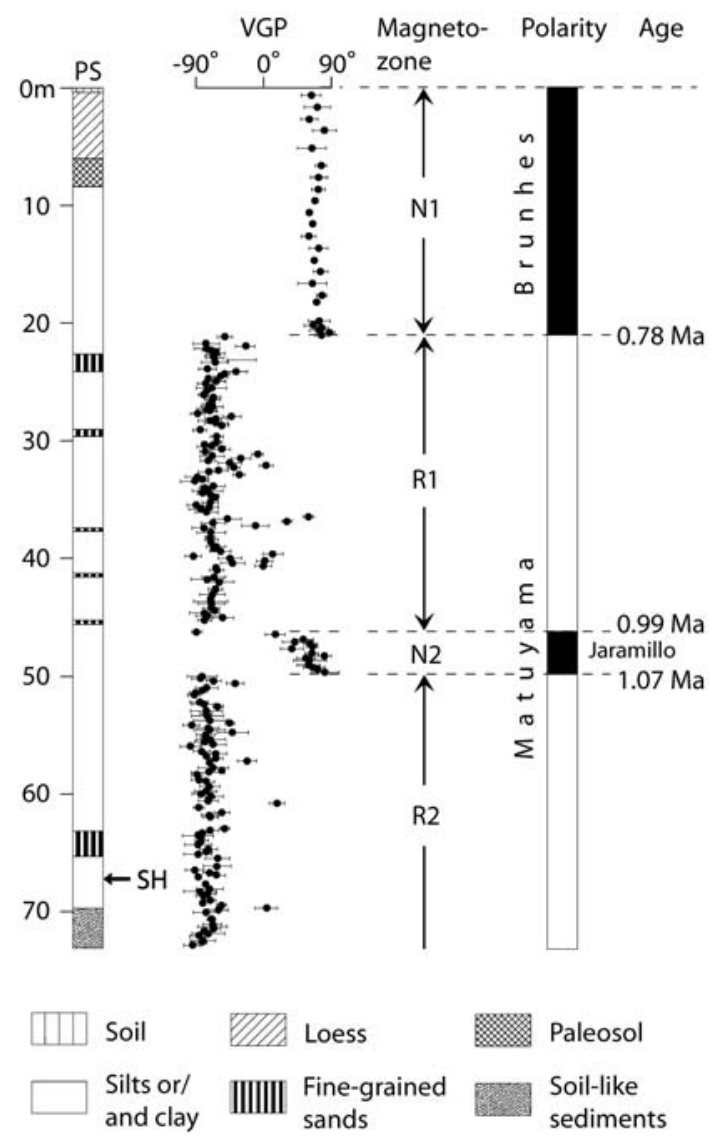

Fig. 3 Columnar section and paleomagnetic data of the Xiaochangliang site modified from Zhu et al. (2001)

The section shows the lithofacies of the sediments from the plateau surface (PS) to the sampling horizon (SH) which is equivalent to the artifact layer of the site. Zhu et al. (2001) dated the artifact layer as 1.36 Ma on the basis of the paleomagnetic data (VGP : vertial geomagnetic pole) from this section as well as the nearby "Donggou" section. Note that the age of the layer was determined by the average accumulation rate between the Jaramillo and Olduvai Subchrons in the "Donggou" section which intercalated the marker layer equivalent to that of the Xiaochangliang site (see text). screen-washing.

\section{Screen-washing}

The excavation, sampling and screen-washing were conducted by one of us (Zhang, Y.Q.) with assistance of two employed villagers in the summer of 2005. More than 1.6 tons of raw sediments taken from the sampling horizon were transported to the riverbed of the Sangganhe River near Xiaodukou (Fig. 1). A doublelayered screen box was used for washing the sediments. The box comprises the upper part with $2.0 \mathrm{~mm}$ mesh screen and the lower part with $0.5 \mathrm{~mm}$ mesh screen. The upper part is removable, but nested into the lower part to prevent sample leakage. Before the screenwashing, the raw sediments were soaked in water to facilitate the following washing procedure. If necessary, large clods of the sediments were crumbled. Then the sediments were stirred in water, until they dissolved completely. The dissolved sediments were poured into the screen box, and then flushed with the box being swayed. After finer grains were completely washed away from the sediments, coarser grains as well as bones and teeth of small vertebrates remained on the screens. They were taken out from the screen box, and dried naturally. Then the bones and teeth were sorted by naked eyes from grains on the $2.0 \mathrm{~mm}$ mesh screen and by using a dissecting microscope from those on the $0.5 \mathrm{~mm}$ mesh screen.

\section{Small mammal fauna}

The previous papers on the Xiaochangliang site (You et al., 1980 ; Tang et al., 1995 ; Chen et al., 1999) reported the occurrence of mammal remains, but most of them were large mammals (Table 1). Among the papers, Tang et al. (1995) is the only paper which describes small mammals, but the specimens described is only two, each of which is assigned to a different form of arvicolid rodents.

The screen-washing procedure mentioned in the preceding chapter has succeeded in collecting 233 specimens of small mammals identifiable at the generic or specific level with confidence. Almost all of the specimens are isolated teeth (Table 2). The specimens are allocated to 10 forms listed in Tables 1 and 2. 
Among the forms, six are classified at the specific level, and comprise five extinct species (Ochotona youngi, Yangia cf. tingi, Borsodia chinensis, Allophaiomys deucalion and Chardinomys nihowanicus) and one extant species (Micromys minutus). Thus in species number, the extinct species are considerably dominant in the small mammal fauna (more than $80 \%$ ).

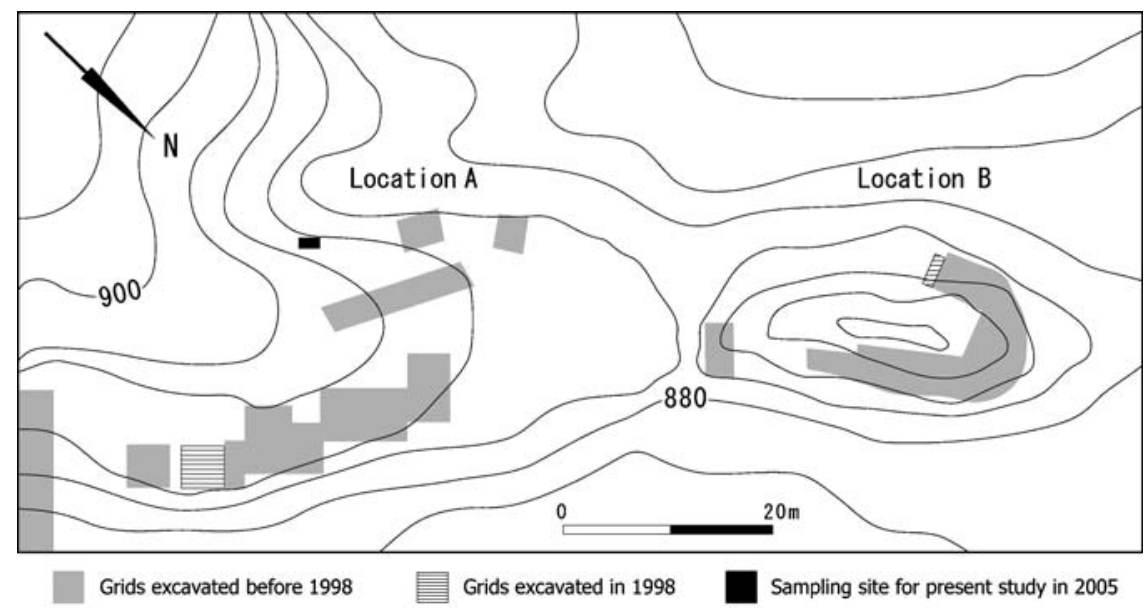

Fig. 4 Detailed plan of the Xiaochangliang site showing the position of the sampling site The plan is cited from Chen et al. (1999) with slight modification.

Table 1 Mammals from the Xiaochangliang site recorded by the previous authors comparing with those by this study

\begin{tabular}{|c|c|c|c|c|}
\hline & You et al. (1980) & Tang et al. (1995) & Chen et al.(1999) & This study \\
\hline $\begin{array}{l}\frac{n}{\pi} \\
\frac{E}{E} \\
\frac{E}{0} \\
\frac{E}{n} \\
\frac{\bar{\sigma}}{E}\end{array}$ & $\begin{array}{l}-------- \\
\text { CARNIVORA } \\
\text { Hyaenasp. } \\
\text { PROBOSCIDEA } \\
\text { Palaeoloxodon sp. }{ }^{* *} \\
\text { PERISSODACTYLA } \\
\text { Hipparion sp. } \\
\text { Equus sanmeniensis } \\
\text { Coelodonta sp. } \\
\text { ARTIODACTYLA } \\
\text { Cervus spp. } \\
\text { Gazella sp. }\end{array}$ & $\begin{array}{l}\text { RODENTIA } \\
\text { Mimomys chinensis* } \\
\text { Allophaiomys cf. } \\
\text { pliocaenicus** } \\
\\
\\
\\
\text { CARNIVORA } \\
\text { Martes sp. } \\
\text { Hyaena licenti } \\
\text { PROBOSCIDEA } \\
\text { Palaeoloxodon sp. *** } \\
\text { PERISSODACTYLA } \\
\text { Proboscidipparion sinense } \\
\text { Hipparion sp. } \\
\text { Equus sanmeniensis } \\
\text { Coelodonta antiquitatis } \\
\text { ARTIODACTYLA } \\
\text { Cervus sp. } \\
\text { Gazella sp. } \\
\text { Bovinae, gen. et sp. indet. }\end{array}$ & $\begin{array}{l}\text { None } \\
\text { PARNIVORA } \\
\text { Viverra sp. } \\
\text { Felidae, gen. et sp. indet. } \\
\text { PROBOSCIDEA } \\
\text { Palaeoloxodon sp. }{ }^{* * *} \\
\text { PERISSODACTYLA } \\
\text { Hipparion sp. } \\
\text { Coelodonta antiquitatis } \\
\text { ARTIODACTYLA } \\
\text { Bison sp. }\end{array}$ & $\begin{array}{l}\text { SORICOMORPHA } \\
\text { SOrex sp. } \\
\text { LAGOMORPHA } \\
\text { Ochotona youngi } \\
\text { Ochotona or } \\
\text { Ochotonoides sp. } \\
\text { RODENTIA } \\
\text { Cricetulus or Phodopus sp. } \\
\text { Yangia cf. tingi } \\
\text { Borsodia chinensis } \\
\text { Mimomys sp. } \\
\text { Allophaiomys deucalion } \\
\text { Micromys minutus } \\
\text { Chardinomys nihowanicus } \\
-\end{array}$ \\
\hline
\end{tabular}

* probably the same as Borsodia chinensis in this study.

** probably the same as Allophalomys deucalion in this study.

** Wei et al. (2006) referred Palaeoloxodon sp. by Tang et al. (1995) to Mammuthus trogontheii. Moreover,

Palaeoloxodon sp. by You et al. (1980) and Chen et al.(1999) are possibly referable to Mammuthus. 
Table 2 Number of the identifiable specimens collected by this study

\begin{tabular}{|c|c|c|}
\hline Small mammal form & $\begin{array}{r}\text { Eleme } \\
\text { Mandible }\end{array}$ & $\begin{array}{l}\text { ent } \\
\text { Isolated } \\
\text { teeth }\end{array}$ \\
\hline $\begin{array}{l}\text { SORICOMORPHA } \\
\text { Soricidae }\end{array}$ & & \\
\hline $\begin{array}{l}\text { Sorex sp. } \\
\text { LAGOMORPHA }\end{array}$ & - & 8 \\
\hline Ochotonidae & & \\
\hline Ochotona youngi & 1 & $35(+15)$ \\
\hline $\begin{array}{l}\text { Ochotona or Ochotonoides sp. } \\
\text { RODENTIA }\end{array}$ & - & 2 \\
\hline Cricetidae & & \\
\hline $\begin{array}{l}\text { Cricetulus or Phodopus sp. } \\
\text { Siphneidae }\end{array}$ & - & 13 \\
\hline $\begin{array}{l}\text { Yangia cf.tingi } \\
\text { Arvicolidae }\end{array}$ & - & 1 \\
\hline Borsodiachinensis & - & 73 \\
\hline Mimomys sp. & - & 2 \\
\hline $\begin{array}{l}\text { Allophaiomys deucalion } \\
\text { Muridae }\end{array}$ & & 61 \\
\hline * Micromys minutus & - & 12 \\
\hline Chardinomys nihowanicus & - & 25 \\
\hline $\begin{array}{l}\text { The number in parenthesis indicates } \\
\text { fragments possibly assigned to Ochot } \\
\text { them are fragments of lower cheek te } \\
\text { break. } \\
\text { * extant species }\end{array}$ & $\begin{array}{l}\text { the number } \\
\text { tona youngi. } \\
\text { eth which ar }\end{array}$ & $\begin{array}{l}\text { Most of } \\
\text { e easy to }\end{array}$ \\
\hline
\end{tabular}

In specimen number, rodents show a high percentage $(80.3 \%)$ in the fauna, while lagomorphs are subordinate (16.3\%), and soricomorphs are much fewer than them (3.4\%). The rodents are composed of such four families as Cricetidae, Siphneidae, Arvicolidae and Muridae, but lack Sciuridae, Castoridae, Rhizomyidae, Dipodidae and Hystricidae which are sometimes found in the Pliocene and Pleistocene of China. Among the four families, Arvicolidae is very abundant, and attains to $72.7 \%$ of all the rodent specimens $(58.4 \%$ of all the small mammal specimens). Almost all the arvicolid specimens are allocated to the extinct vole with rooted molars, Borsodia chinensis, and to the other extinct vole with rootless molars, Allophaiomys deucalion. The remainders are only two specimens, which are assigned to the extinct vole genus Mimomys. Arvicolidae is followed by Muridae in specimen number, which occupies $19.8 \%$ of the rodent specimens $(15.9 \%$ of the total). About two thirds of the murid specimens are allocated to the extinct mouse with characteristic molars, Chardinomys niho- wanicus, while the remainders are referred to the extant harvest mouse, Micromys minutus. The specimens of Cricetidae are much fewer $(7.0 \%$ of the rodent specimens), and belong to the extant hamster genus Cricetulus or Phodopus. Only one specimen of Siphneidae is recognized in the rodent specimens, and is referred to the extinct mole-rat, Yangia cf. tingi.

All the lagomorph specimens are assigned to Ochotonidae, while Leporidae is absent in the specimens. They are classified into a smaller form referable to the extict pika, Ochotona youngi, and a larger form, Ochotona or Ochotonoides sp. The former is a relatively abundant element in the small mammal fauna, and occupies $15.5 \%$ of all the small mammal specimens. If the fragments possibly assigned to $O$. young $i$ are added, its percentage becomes higher (see Table 2).

All the soricomorph specimens are referred to the extant shrew genus Sorex.

\section{Comparison with other faunas}

The small mammal fauna of the Xiaochangliang site is compared with those of paleomagnetically and/or radiometrically dated sediments in the Nihewan Basin and its adjacent area, which are the faunas of the three layers of Qianjiashawa-Donggou, the new cultural layer of Majuangou, Layers 4 to 11 of Locality 1 of the Zhoukoudian site in Beijing, and Upper Cave of the same site (Fig. 5).

The small mammal faunas of QianjiashawaDonggou were reported by Zheng et al. (2006). They referred to the locality situated $500 \mathrm{~m}$ northeast of the village of Qianjiashawa as Donggou, although Zhu et al. (2001) already used the same place-name "Donggou" as mentioned in the previous chapter. Donggou by the former authors is obviously different from "Donggou" by the latter authors in geographic position, and both of them are probably $1.5 \mathrm{~km}$ apart from each other. Furthermore, they are also different in elevation. The section shown in Zheng et al. (2006) is considered to be placed lower than the "Donggou" section of Zhu et al. (2001). To avoid confusion, we here use QianjiashawaDonggou for Donggou of Zheng et al. (2006) which means Donggou near Qianjiashawa, and "Donggou" for the same place-name by Zhu et al. (2001). 

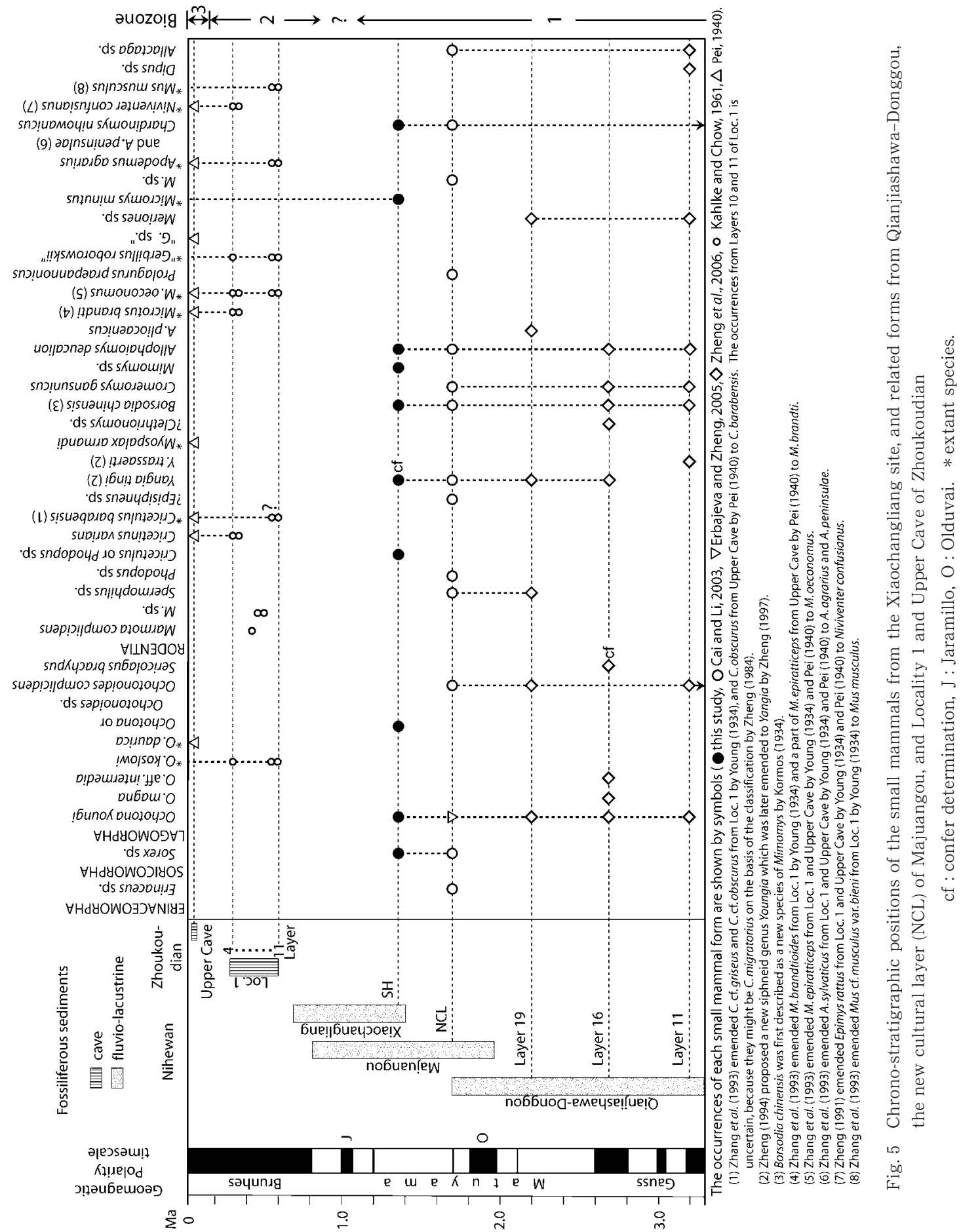
In the Qianjiashawa-Donggou section, seven layers yield small mammal remains. The faunas of the upper three (Layers 11, 16 and 19) of the seven are compared with the fauna of the Xiaochangliang site. These layers were dated from the late Gauss Chron to early Matuyama Chron by paleomagnetic measurements (Yang et al., 1996, Fig. 5), although Zheng et al. (2006) considered the Gauss/Matuyama boundary placed at Layer 11 on the basis of small mammal faunas. The faunas of these layers comprise only extinct species, when small mammal forms classified at the specific level are concerned. Among the extinct species, Ochotona youngi, Yangia tingi, Borsodia chinensis and Allophaiomys deucalion are common to the fauna of the Xiaochangliang site. These species occur from two layers or more in QianjiashawaDonggou, and are possibly major elements. Furthermore, they are dominant and/or characteristic elements in the fauna of the Xiaochangliang site. Thus the overall characters of both the faunas are similar to each other. But a few minor differences are also observed between them. The faunas of Qianjiashawa-Donggou contain such extinct species as Ochotona magna, O. aff. intermedia, Ochotonoides complicidens, Sericolagus cf. brachypus, Yangia trassaerti, Cromeromys gansunicus and Allophaiomys pliocaenicus, which are absent from the fauna of the Xiaochangliang site. Most of them occur from only one layer in Qianjiashawa-Donggou, and are possibly minor elements. Additionally, the fauna of the Xiaochangliang site contains one extant species.

The small mammal fauna of the new cultural layer of Majuangou was described by Cai and $\mathrm{Li}$ (2003). This layer is equivalent to MJG-III of Zhu et al. (2004) and the artifact horizon of the Goudi site by Gao et al. (2005). Zhu et al. (2004) determined the age of the layer as $1.66 \mathrm{Ma}$ by paleomagnetic measurements. Cai and Li (2003) also reported the specimen numbers of the mammal remains obtained, and thus it is possible to compare the abundance of each small mammal form between the new cultural layer and the Xiaochangliang site.

All the small mammal forms classified at the specific level are extinct in the new cultural layer, while the small mammals of the Xiao- changliang site contain extant species in a low percentage (less than 20\%), as mentioned before.

In the new cultural layer, arvicolid rodents are highly predominant as in the Xiaochangliang site. They comprise four forms, among which two are common to the fauna of the Xiaochangliang site (B. chinensis and A. deucalion). One of the remaining two, Prolagurus praepannonicus is an extinct vole with rootless molars, and is abundant in the fauna of the new cultural layer. The identification with this species is problematic, because it does not occur from all the other faunas compared (Fig. 5). Murid rodents are abundant in the fauna of the new cultural layer as in that of the Xiaochangliang site. Moreover the components of the murids (Micromys sp. and Chardinomys nihowanicus) and their relative abundance are similar to those in the Xiaochangliang site. In siphneid rodents, $Y$. ting $i$ is common to both of the faunas, and is rare in both of them. Ochotonid lagomorphs are also composed of a smaller and larger forms, as in the fauna of the Xiaochangliang site. The smaller form is allocated to $O$. minor by Cai and Li (2003), but is probably identical with $O$. youngi, judging from the description of Erbajeva and Zheng (2005). Leporid lagomorphs are absent, as in the fauna of the Xiaochangliang site. It can be concluded that the fauna of the new cultural layer generally resembles that of the Xiaochangliang site.

The small mammal remains from Locality 1 and Upper Cave of the Zhoukoudian (Choukoutien) site were described in the monographs of Young (1934) and Pei (1940). The classification of some small mammal forms was later emended by Zheng (1984, 1991) and Zhang et al. (1993). Kahlke and Chow (1961) showed the stratigraphic distributions of mammals in the thick sediments of Locality 1 , which are shown in Figure 5 with the later emendation. On the other hand, the sediments of the two localities were dated by paleomagnetic, radiometric and other non-faunal methods, and the results were summarily given in Li et al. (1985) and Zhao et al. (1985). On the basis of them, the chronological positions of the two localities are shown in Figure 5.

The small mammal faunas of Locality 1 and 
Upper Cave are considerably different from that of the Xiaochangliang site. All the extinct species occurred from the site are absent in the faunas of Locality 1 and Upper Cave, which are dominated by extant species (Fig. 5). They also differ in having more diversified faunas, which include sciurid, castorid, rhizomyid and hystricid rodents as well as leporid lagomorphs, although the difference in diversity partly depends on that in their sedimentary conditions (cave versus fluvio-lacustrine, as shown in Fig. 5).

\section{Biostratigraphy}

On the basis of the data given in Figure 5, we discuss the biostaratigraphy of small mammals herein. The faunas of Qianjiashawa-Donggou (Layers 11, 16 and 19) are similar to that of the new cultural layer of Majuangou (NCL in Fig. 5). Both of them include no extant species, and are characterized by the occurrences of such extinct species as Ochotona youngi, Ochotonoides complicidens, Yangia tingi, Borsodia chinensis, Cromeromys gansunicus and Allophaiomys deucalion. Thus they constitute a single zone (biozone 1 in Fig. 5). The fauna of the Xiaochangliang site (SH in Fig. 5) is generally similar to those of the underlying sediments (Layers 11, 16 and 19, and NCL), and differs only in having the extant species, Micromys minutus. On the basis of the overall similarity, it can be regarded that the biozone 1 includes the fauna of the Xiaochangliang site which represents its uppermost stage (Fig. 5). The fauna of Locality 1 is considerably different from that of the Xiaochangliang site in much higher percentage of extant species and higher diversity of small mammals. The clear difference leads to recognize a different zone (biozone 2 in Fig. 5). The boundary between the biozones 1 and 2 is obscure, because well-dated information on small mammals is laking in the time interval between the age of the Xiaochangliang site and Locality 1. The biozone 3 represented by the fauna of Upper Cave is distinguished from the biozone 2 by its more modernized nature of the fauna (for example, very low percentage of extinct species).

\section{Faunal turnover}

The fauna of the biozone 1 is composed mostly of the extinct species characterizing the Late Pliocene and Early Pleistocene of northern China (for example, Ochotona youngi, Borsodia chinensis, Allophaiomys deucalion and Chardinomys nihowanicus). This fauna was somewhat changed between $1.66 \mathrm{Ma}$ and $1.36 \mathrm{Ma}$ by the appearance of the extant species, Micromys minutus, in the uppermost stage of the biozone 1 . Much greater change occurred between 1.36 Ma and 0.6 Ma, namely between the biozones 1 and 2. The extinct species disappeared completely, and were replaced by many extant species characteristic to the fauna of the biozone 2 (for example, extant species of Ochotona, Microtus, Apodemus, Niviventer and Mus). This change is important for considering the origin of the present-day fauna of northern China. The timing, process and environmental backgrounds of the change are expected to be clarified by future studies on small mammal faunas dated between 1.36 and $0.6 \mathrm{Ma}$.

\section{Paleoenvironment}

The small mammal specimens obtained by the present study are relatively well-preserved, and show no trace of water abrasion by transportation. Thus it is inferred that carcasses of small mammals inhabiting near an ancient lake were transported for short distance into the lake or an flood plain along it by running water, and their bones and teeth were buried by rapid sedimentation. This inference is roughly consistent with the taphonomic process of artifacts and larger mammal remains from the Xiaochangliang site stated by Chen et al. (1999).

The small mammal fauna of the site consists mainly of temperate grassland elements. Extant species of Ochotona live mostly in open plains and steppes, often associated with rocky outcrops. The abundant occurrence of Ochotona in the fauna suggests a similar vegetation. Extant species of Cricetulus and Phodopus prefer arid areas (steppe to semi-desert), and thus the occurrence of Cricetulus or Phodopus sp. in the fauna also indicates arid environment. The arvicolid species highly predominant in the fauna (Borsodia chinensis and Allophaiomys deucalion) have high-crowned prismatic molars adaptive to grass-eating. This suggests that they are grassland dwellers. The extant species, 
Micromys minutus, mainly inhabits areas with tall grasses and bushes along rivers, ponds and lakes. This also suggests grasslands with shrubs near a lake.

Apart from the small mammals, grassland vegetation is also suggested by such larger mammals as horses (Proboscidipparion sinense, Hipparion sp. and Equus sanmeniensis) reported from the site by the previous authors (Table 1). Palaeoloxodon sp. also reported by them were recently emended as the steppe mammoth, Mammuthus trogontherii, by Wei et al. (2006), which is considered to have lived mainly in grasslands.

The paleoenvironment around the site is inferred to have been grasslands with sparse shrubs near a lake under temperate climate. It is almost identical with the paleoenvironment reconstructed for the new cultural layer of Majuangou by Cai and Li (2003). Thus the environment had not changed from $1.66 \mathrm{Ma}$ to 1.36 Ma.

\section{Conclusion}

The knowledge on the small mammal fauna of the Xiaochangliang site with the age of 1.36 Ma has greatly expanded by the present study. The fauna comprises 10 forms identifiable at the generic or specific level, among which five are extinct species, and one is extant species (Tables 1 and 2). In species number, therefore, more than $80 \%$ are extinct. In specimen number, $80.3 \%$ of the identifiable specimens are rodents. Among the rodents, the arvicolids are highly predominant $(72.7 \%$ of the rodent specimens), the murids are subordinate (19.8\%), the cricetids are much fewer (7.0\%), and the siphneids are rare $(0.4 \%)$. Almost all the arvicolid specimens are allocated to such extinct species as Borsodia chinensis and Allophaiomys deucalion. The lagomorphs are much fewer than the rodents (16.3\% of the identifiable specimens). Most of the lagmorphs are assigned to the extinct species, Ochotona youngi.

The small mammal fauna of the Xiaochangliang site is compared with the four faunas from the well-dated sediments in the Nihewan Basin and the adjacent area (QianjiashawaDonggou, the new cultural layer of Majuangou, and Locality 1 and Upper Cave of the Zhou- koudian site, Fig. 5). The faunal comparison results in recognizing the three small mammal biozones, among which the uppermost stage of the lowest biozone is represented by the fauna of the Xiaochangliang site. The faunal turnover is also considered. The fauna dominated by the extinct species characterizing the Late Pliocene and Early Pleistocene of northern China was somewhat changed between 1.66 Ma and $1.36 \mathrm{Ma}$ by the appearance of the extant species (Micromys minutus). Much greater change occurred between 1.36 Ma and 0.6 Ma. During this period, the above-mentioned extinct species disappeared, while many extant species newly appeared. This change resulted in the modernization of the fauna. As regards the paleoenviornment, the fauna of the Xiaochangliang site indicates grasslands with sparse shrubs near a lake under temperate climate.

\section{Acknowledgments}

We are grateful for the helpful discussion with Professor Shaohua Zheng from Institute of Vertebrate Paleontology and Paleoanthropology, Chinese Academy of Sciences. We also acknowledge the great convenience provided for the present study by Professor Shusaku Yoshikawa and the graduate students of Natural History of Anthropogene Laboratory, Graduate School of Science, Osaka City University. The present study was supported by the National Science Foundation of China (Grant No. 40472012).

\section{References}

Breuil, H. (1935) L'état actuel de nos connaissances sur les industries paléolithiques de Choukoutien. L'anthropologie, 45, 740-746.

Cai, B.Q. and Li, Q. (2003) Human remains and the environment of Early Pleistocene in the Nihewan Basin. Science in China, Ser. D, 33, 418-424. (C)

Cai, B.Q., Zhang, Z.Q., Zheng, S.H., Qiu, Z.D., Li, Q. and Li, Q. (2004) New advances in the stratigraphic study on representative sections in the Nihewan Basin, Hebei. Professional Papers of Stratigraphy and Palaeontology, 28, 267-285. (C+E)

Chen, C., Shen, C., Chen, W.Y. and Tang, Y.J. (1999) 1998 excavation of the Xiaochangliang site at Yangyuan, Hebei. Acta Anthoropologica Sinica, 18, 225239. $(\mathrm{C}+\mathrm{E})$

Erbajeva, M.A. and Zheng, S.H. (2005) New data on Late Miocene-Pleistocene ochotonids (Ochotonidae, Lagomorpha) from North China. Acta Zoologica Cra- 
coviensia, 48A, 93-117.

Gao, X., Wei, Q., Shen, C. and Keates, S. (2005) New light on the earliest hominid occupation in East Asia. Current Anthropology, 46 (supplement), 115120.

Kahlke, H.D. and Chow, B.S. (1961) A summary of stratigraphical and paleontological observations in the lower layers of Choukoutien, Locality 1, and on the chronological position of the site. Vertebrata PalAsiatica, 1961, 212-240. (C+E)

Kormos, T. (1934) Première preuve de l'existence du genre Mimomys en Asie orientale. Travaux du Laboratoire de Géologie de la Faculté des Sciences de Lyon, 24, 3-8.

Li, X.G., Liu, G.L., Xu, G.Y., Wang, F.L., Chou, S.H. and Cai, L.Z. (1985) Radiocarbon dating of fossil mammal bones from the Upper Cave and New Cave of Zhoukoudian. Multi-disciplinary study of the Peking Man site at Zhoukoudian : 261-262, Science Press. (C)

Pei, W.C. (1940) The Upper Cave fauna of Choukoutien. Palaeontologia Sinica, New Ser. C, 10, 1-101.

Tang, Y.J., Li, Y. and Chen, W.Y. (1995) Mammalian fossils and the age of Xiaochangliang paleolithic site of Yangyuan, Hebei. Vertebrata PalAsiatica, 33, 74-83, pl. 1. $(\mathrm{C}+\mathrm{E})$

Wei, G.B., Taruno, H., Kawamura, Y. and Jin, C.Z. (2006) Pliocene and Early Pleistocene primitive mammoths of northern China : Their revised taxonomy, biostratigraphy and evolution. Journal of Geosciences, Osaka City University, 49, 59-101.

Wei, Q. (1997) The framework of archaeological geology of the Nihewan Basin. Tong, Y.S., Zhang, Y.Y., Wu, W.Y., Li, J.L. and Shi, L.Q. (eds.) Evidence for evolution-Essays in honor of Prof. Chungchien Young on the hundredth anniversary of his birth : 193-207, China Ocean Press. (C+E)

Yang, Z.G., Lin, H.M., Zhang, G.W. and Wang, S.J. (1996) Lower Pleistocene in the Nihewan Basin. Yang, Z.G. and Lin, H.M. (eds.) Quaternary stratigraphy in China and its international correlation : 109-130, Geological Publishing House. (C)

You, Y.Z., Tang, Y.J. and Li, Y. (1980) Discovery of the paleoliths from the Nihewan Formation. Quaternaria Sinica, 5, 1-11. (C)

Young, C.C. (1934) On the Insectivora, Chiroptera, Ro- dentia and Primates other than Sinanthropus from Locality 1 at Choukoutien. Palaeontologia Sinica, Ser. C, 8, fasc. 3, 1-161.

Zhang, S.S., Wang, C.L., Li, Y.S., Cui, D.W., You, Y.Z., Han, D.F., Ye, X.K., Hou, L.H., Zheng, S.H., Yu, Q.L., Wang, P.F., Xia, Y.M. and Chen, W.Y. (1993) Comprehensive study on the Jinniushan paleolithic site. Memoirs of Institute of Vertebrate Palaeontology and Palaeoanthropology, Academia Sinica, 19, 1163, pl. 1-16. (C+E)

Zhao, S.S., Pei, J.X., Guo, S.L., Liu, S.S., Qian, F., Chou, S.H. and Li, X.G. (1985) Study of chronology of Peking Man site. Multi-disciplinary study of the Peking Man site at Zhoukoudian : 239-240, Science Press. (C)

Zheng, S.H. (1984) Revised determination of the fossil Cricetinae (Rodentia Mammalia) of Choukoutien District. Vertebrata PalAsiatica, 22, 179-197. (C+E) Zheng, S.H. (1991) Rodentia Bowdich, 1821. Wushan hominid site : $52-85$, China Ocean Press. $(\mathrm{C}+\mathrm{E})$

Zheng, S.H. (1994) Classification and evolution of the Siphneidae. National Science Museum Monographs, 8, 57-76.

Zheng, S.H. (1997) Evolution of the Mesosiphneinae (Siphneidae, Rodentia) and environmental change. Tong, Y.S., Zhang, Y.Y., Wu, W.Y., Li, J.L. and Shi, L.Q. (eds.) Evidence for evolution-Essays in honor of Prof. Chungchien Young on the hundredth anniversary of his birth : 137-150, China Ocean Press. (C $+\mathrm{E})$

Zheng, S.H., Cai, B.Q. and Li, Q. (2006) The Plio-Pleistocene small mammals from Donggou section of Nihewan Basin, Hebei, China. Vertebrata PalAsiatica, 44, 320-331. (C+E)

Zhu, R.X., Hoffman, K.A., Potts, R., Deng, C.L., Pan, Y. X., Guo, B., Shi, C.D., Guo, Z.T., Yuan, B.Y., Hou, Y.M. and Huang, W.W. (2001) Earliest presence of humans in northeast Asia. Nature, 413, 413-417.

Zhu, R.X., Potts, R., Xie, F., Hoffman, K.A., Deng, C.L., Shi, C.D., Pan, Y.X., Wang, H.Q., Shi, R.P., Wang, Y. C., Shi, G.H. and Wu, N.Q. (2004) New evidence on the earliest human presence at high northern latitudes in northeast Asia. Nature, 431, 559-562.

(C) in Chinese, $(\mathrm{C}+\mathrm{E})$ in Chinese with English abstract or summary. 


\title{
中国河北省泥河湾盆地小長梁遺跡の前期更新世 小型哺乳動物群
}

\author{
張 穎 奇*1 河 村 善 也*2, a - 蔡 保 全*3
}

\begin{abstract}
〔要旨〕
小長梁遺跡は前期更新世の人工遺物を出土する遺跡と して重要であるが，その遺物包含層と同一層準から採取 した大量の堆積物を細かい目の篩で水洗して，多くの小 型哺乳類化石を得た，遺物包含層の年代は古地磁気測定 により $1.36 \mathrm{Ma}$ とされている. 小型哺乳類は生層序の研 究や古環境復元に重要であるが，この遺跡ではこれまで 小型哺乳類化石はほとんど採集されてこなかった。今回 は得られた化石をあとに，この遺跡の小型哺乳類の動物 群の特徵を明らかにし, それを近隣の地域にあって古地 磁気層序や放射年代が明確な 4 つの化石産地の動物群と 比較した。 それらにもとづいて, 後期鮮新世とそれ以降

の時期の地層における小型哺乳類の生層序と, それらの 時期の小型哺乳類の動物相の変遷について論議した．変 遷については, 絶滅種が卓越する後期鮮新世から前期更 新世にかけての中国北部の動物相が $1.66 \mathrm{Ma}$ と 1.36 $\mathrm{Ma}$ の間に現生種 (カヤネズミ)の出現により若干変化 したあと, $1.36 \mathrm{Ma}$ と 0.6 Ma の間には多くの絶滅種が 見られなくなる一方で, 現生種が数多く出現するという 大きな変化があったと考えられる，さらに，この遺跡周 辺の前期更新世の古環境については, 温帯の気候で, 湖 の近くにまばらに灌木の生えた草原という環境が推定さ れた.
\end{abstract}

キーワード : 小型哺乳動物群, 生層序, 前期更新世, 小長梁遺跡, 泥河湾盆地, 中国

*1 中国科学院古春椎動物古人類研究所 中国北京市 643 信箱 (現住所 : 大阪市立大学大学院理学研究科 $\overline{\mathbf{T}} 558-8585$ 大阪 市住吉区杉本 3-3-138).

*2 愛知教育大学自然科学系理科教育講座地学領域 $\overline{\mathbf{T}} 448$-8542 刚谷市井ヶ谷町広沢 1.

*3 厦門大学歴史系 中国福建省厦門市.

*a Corresponding author : yskawamr@auecc.aichi-edu.ac.jp 